\title{
PARTISIPASI POLITIK ONLINE GENERASI Z PADA PEMILIHAN PRESIDEN INDONESIA 2019
}

\author{
HENI PUTRI YOLANDA ${ }^{1}$ \& UMAR HALIM ${ }^{2}$
}

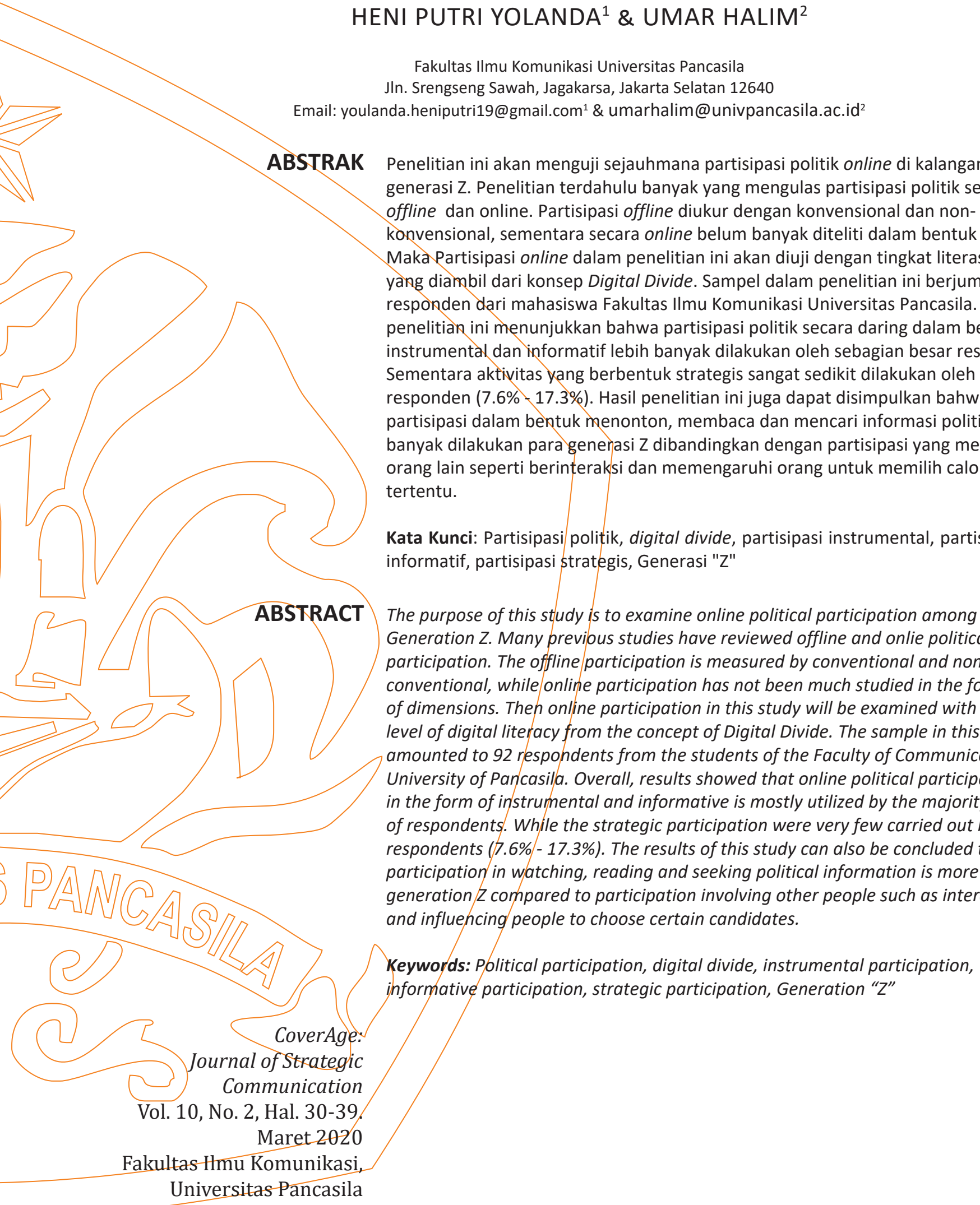

Diterima 6 Januari 2020

Disetujui 2 Maret 2020 


\section{PENDAHULUAN}

Penggunaan internet terkhusus media sosial tidak melulu untuk eksistensi diri, namun dapat digunakan untuk hal lainnya seperti ikut serta berpartisipasi mengenai isu politik. Partisipasi politik dalam Arifin (2013: 67) disebutkan sebagai bentuk keterlibatan warga negara secara personal dalam kegiatan politik dengan bermacam-macam level pada sistem politik. Ditambahkan lagi oleh Budiardjo (2013: 367) bahwa partisipasi politik adalah keterlibatan perorangan atau sekelompok orang untuk ikut serta secara aktif dalam kehidupan politik. Maka, dengan keterlibatan orang-orang tersebut dapat berfungsi untuk mempengaruhi kebijakan politik atau kebijakan yang menyangkut banyak orang dari segala sisi kehidupan berbangsa dan bernegara.

Partisipasi sangat penting khususnya di negara demokrasi karena dapat sebagai tolok ukur kepedulian warga negara terhadap negaranya. Karena apabila masyarakat merasa bagian dari sistem kehidupan bernegara, maka dengan sendirinya akan memikirkan isu negara demi turut menentukan kemajuan kehidupan bangsa dan negaranya (Harun \& Sumarno, 2006: 133). Sehingga dengan kepedulian masyarakat akan politik, para pemerintah akan terawasi dengan baik.

Sadar atau tidak sadar, perkembangan teknologi digital khususnya media baru dan media sosial mempengaruhi partisipasi politik masyarakat (Akmal \& Salman, 2015). Jika dulu partisipasi politik dilakukan secara 'tradisional' (tanpa penggunaan media baru), namun sekarang partisipasi politik juga dapat dilakukan di media baru bahkan media sosial (Salman \& Saad, 2015; Halim \& Dyah, 2019).

Partisipasi tradisional yang dahulu sering dilakukan seperti berbicara tatap muka dengan kerabat mengenai isu politik, demo, kampanye dan sebagainya, kemudian bertransformasi menjadi partisipasi online yaitu saling beradu argumen/ pendapat di kolom komentar sosial media, mengkampanyekan pemimpin pilihannya melalui unggahan kontennya di media sosial, hingga yang bersifat non-konvensional seperti membuat meme untuk menjatuhkan kandidat lainnya. Sehingga terlihat jelas bahwa secara disengaja atau tidak, dengan ikut sertanya warga dunia maya terlibat aktivitas politik di media sosial, mereka sudah melakukan partisipasi politik daring.

Semua kalangan tanpa terkecuali memiliki porsi yang sama untuk dapat berpartisipasi dalam hal isu politik. Apalagi ditambah dengan kecanggihan era digital ini memudahkan setiap orang untuk berekspresi, terutama generasi z yang sudah memiliki hak pilih dan terpapar kecanggihan internet sejak kecil akan lebih mudah untuk berpartisipasi politik. Salah satu tempat dengan jumlah generasi z cukup banyak serta memiliki beragam jenis orang dan latar belakangnya adalah lingkungan kampus. Karena di lingkungan kampus berbagai macam latar belakang demografis seseorang berkumpul untuk belajar bagi para mahasiswa.

Salah satu Universitas yang berada di Jakarta tersebut adalah Universitas Pancasila yang beralamat di Srengseng Sawah, Jakarta Selatan. Penelitian ini mengambil sampel dari mahasiswa komunikasi yang mana mahasiswa komunikasi cukup sering mengulas bahasan politik di dalam pembelajarannya sehingga besar kemungkinan para responden setidaknya pernah terpapar informasi politik yang menyebabkan mereka turut melakukan partisipasi politik juga.

Kemudian, partisipasi politik saat ini juga sedang hangat-hangatnya diperbincangkan di media online, bahkan tidak jarang berujung pada saling serang argumen antar kubu pendukung bakal calon pasangan. Mengingat isu pilpres 2019 memang sedang menjadi perhatian rakyat Indonesia. Pilpres tahun 2019 mengusung 2 calon kandidat yaitu Joko Widodo-KH Ma'ruf Amin dan Prabowo SubiantoSandiaga Salahudin Uno. Masing-masing kubu pendukung yang radikal saling menyerang kandidat lawan dan mengelu-elukan kandidat pilihannya. Sebutan 'cebong' untuk para pendukung JokowiMa'ruf Amin dan 'kampret' untuk para pendukung Prabowo-Sandiaga tak asing terdengar saat Pilpres.

Beragam cara para 'cebong' dan 'kampret ini mengekspresikan dukungannya pada kandidat pilihan serta 'serangannya' terhadap kandidat lawan seperti membuat meme, mengunggah konten (seperti video, foto, gambar, karikatur, dan sebagainya), serta berdebat pada kolom komentar. Serta sempat ramai di media sosial para pendukung radikal menggunakan hastag \#2019GantiPresiden dan \#2019TetapJokowi di setiap unggahan konten mereka di media baru.

Untuk dapat membuat meme, mengunggah konten, dan sebagainya tentu tidak hanya dibutuhkan material seperti ponsel pintar dan aplikasinya, namun juga keahlian menggunakan itu semua (Dijk, 2008). Sehingga dengan kata lain, partisipasi politik yang dilakukan di media 
sosial memiliki tingkatannya sendiri sesuai dengan keahlian digital yang dimilikinya juga. Semakin tinggi keahlian seseorang, semakin rumit juga tingkat partisipasi politik yang dilakukannya.

Dari banyaknya penelitian, peneliti belum melihat penelitian yang secara khusus mengangkat tentang partisipasi politik secara daring yang dikaitkan dengan literasi digital para penggunanya. Maka peneliti ingin mengetahui sejauhmana tingkat partisipasi politik secara daring para generasi Z?

\section{TINJAUAN PUSTAKA}

\section{Partisipasi Politik}

Partisipasi politik merupakan salah satu konsep yang sangat terkenal di dalam ilmu politik (Rohaniah \& Efrizah, 2015: 468). Terutama untuk negara yang menganut sistem politik demokrasi, karena pemikiran yang melandasi konsep ini adalah pemerintahan yang dari rakyat, oleh rakyat dan untuk rakyat (Mudjiyanto, 2012). Namun sebenarnya pada awal studi, konsep ini fokus kepada partai politik sebagai pelaku utamanya, kemudian seiring berkembangnya demokrasi mulai bermunculan masyarakat-masyarakat yang kecewa terhadap kinerja partai politik karena kecenderungannya yang hanya terfokus pada masalah tertentu saja, sedangkan masih banyak masalah lain juga yang harus diselesaikan. Harapan dari gerakan masyarakat ini dengan turut serta mempengaruhi proses pengambilan keputusan mengenai kebijakan kenegaraan akan lebih efektif mempengaruhi proses pengambilan keputusan yang dilakukan aparat pemerintahan dengan aksi langsung masyarakat (Rohaniah \& Efrizah, 2015: 469).

Untuk memperoleh pengertian yang lebih luas dan lengkap dari ruang lingkup konsep partisipasi politik dibutuhkan definisi dari parah ahli. Namun, banyak para ahli yang menyatakan definisinya, tidak terlalu banyak perbedaan-perbedaan tiap definisi (Syafiyyah, 2003: 47). Menurut Budiardjo (2013: 367) partisipasi politik adalah kegiatan perorangan atau sekelompok orang untuk ikut serta secara aktif dalam kehidupan politik. Pada negara penganut sistem demokrasi, konsep ini berawal dari paham bahwa kedaulatan negara berada di tangan rakyat yang pelaksanaannya dapat dilakukan oleh rakyat demi menentukan orang-orang yang akan memegang tongkat pemerintahan.

Indonesia sebagai negara demokrasi juga menganut paham tersebut yang mana kekuasaan berada di tangan rakyat oleh rakyat dan untuk rakyat. Maka dari itu, partisipasi politik merupakan salah satu aspek yang penting dari demokrasi (Surbakti, 2007: 179). Demokrasi tidak akan berfungsi tanpa aktivitas atau tindakan minimum yang dilakukan warga negara dalam partisipasi politik.

Partisipasi politik yang dikehendaki adalah partisipasi yang tumbuh atas kesadaran diri sendiri, karena merasa bagian dari sistem kehidupan bernegara yang dituntut untuk memikirkan isu negara demi turut menentukan kemajuan kehidupan bangsa dan negaranya (Harun \& Sumarno, 2006: 133). Pada sumber yang lain dikatakan bahwa semakin tinggi tingkat kesadaran bernegara, semakin tinggi pula tingkat partisipasi untuk mengikuti, memahami masalah, serta keinginan untuk melibatkan diri dalam kegiatan kegiatan politik bernegara. Demikian juga sebaliknya, apabila tingkat partisipasi rendah dapat dikatakan keadaan genting karena dapat diartikan bahwa banyak masyarakat kurang atau bahkan tidak menaruh perhatian terhadap masalah kenegaraan (Budiardjo, 2013: 367).

Almond dalam Dewi (2017:75) membagi bentuk partisipasi menjadi dua bentuk yaitu, partisipasi politik konvensional dan non konvensional. Partisipasi politik konvensional memiliki pengartian suatu bentuk partisipasi politik yang wajar serta legal dalam demokrasi modern. Bentuk partisipasi yang wajar tersebut dapat meliputi pemungutan suara, diskusi politik, membentuk dan bergabung dengan kelompok kepentingan politik, serta memiliki komunikasi antarpribadi dengan pejabat publik.

Sedangkan partisipasi nonkonvensional memiliki pengertian partisipasi politik yang tidak umum dilakukan dalam kondisi normal bahkan tidak jarang bersifat ilegal disertai dengan kekerasan dan cenderung menghendaki perubahan secara menyeluruh dan mendasar (revolusioner). Contoh partisipasi politik nonkonvensional seperti pengajuan petisi, demonstrasi, konfrontasi, mogok kerja, kekerasan politik benda seperti pengerusakan atau pembakaran, kekerasan politik manusia seperti penculikan atau peneroran, hingga perang gerilya.

Berkembangnya teknologi digital saat ini berdampak besar bagi aspek komunikasi lainnya, tidak terkecuali partisipasi politik yang juga semakin berkembang mengikuti perkembangan era digital. Media baru yang ada sekarang dapat mewadahi partisipasi politik dengan cara baru melalui 
koneksi internet. Sehingga bentuk partisipasi politik tersebut dapat digolongkan lagi menjadi dua berdasarkan penggunaan media baru yaitu online dan offline (Perangin-angin \& Zainal, 2018; Salman \& Saad, 2015; Akmal \& Salman, 2015), atau bisa juga disebut partisipasi politik tradisional dan modern (Rasul, Rahim, \& Salman, 2015).

Jika awalnya bentuk partisipasi politik hanya dilakukan secara offline seperti menandatangani petisi, unjuk rasa, diskusi tatap muka dengan tokoh masyarakat (Rasul, Rahim, \& Salman, 2015), menghadiri pertemuan, memberikan bantuan dana kepada kandidat pemimpin terpilih, berdiskusi secara tatap muka mengenai isu politik (Akmal \& Salman, 2015), menggunakan hak suara pada pemilu (Perangin-angin \& Zainal, 2018), dan yang lainnya. Sekarang, aktivitas partisipasi politik tersebut dapat diwadahi oleh internet secara online seperti mendapatkan informasi dari konten yang diunggah orang lain, dapat bebas berekspresi menyatakan pendapat di akun media sosialnya atau dikolom komentar posting-an orang lain terkait pemerintahan saat ini, media interaktif untuk melihat aktivitas kandidat politik dalam melayani rakyat (Salman, Salleh, Yusoff, \& Abdullah, 2018).

Ditambahkan oleh Mudjiyanto (2012) yaitu penggunaan mesin pencarian, mengerti tentang alamat website, penggunaan e-mail, blog, serta menjadi inisiator diskusi pada blog atau aplikasi jejaring sosial. Lebih spesifik lagi partisipasi politik dalam media sosial yaitu menjadi pengikut akun partai politik atau kandidatnya, memberikan dukungan atau opini (like atau comment) melalui media sosial, membagikan informasi yang diterimanya (share), ada juga yang hanya sekedar melihat/membaca/menonton konten politik yang mereka terima tanpa memberikan respon (Atmodjo, 2014).

Dengan adanya media baru memberikan beragam kemudahan kepada masyarakat untuk turut serta aktif berpartisipasi dalam politik bernegara, contohnya masyarakat tidak harus berorasi didepan umum untuk memberikan "uneg-uneg"nya terkait pemerintah, namun bisa hanya dengan menulis blog pribadi atau mengirimkan e-mail secara pribadi dengan tokoh pemerintah tersebut. Masyarakat juga tidak harus bertemu langsung dengan orang lain jika ingin berdiskusi mengenai permasalahan politik, bisa melalui chat pribadi atau grup di media sosial seperti Whatsapp dll.

\section{Literasi Digital}

Internet hakikatnya berfungsi untuk mengurangi kesenjangan di tengah-tengah masyarakat sosial, seperti kesenjangan informasi dan edukasi. Namun pada prakteknya internet pun memiliki masalah kesenjangannya sendiri di tengah para penggunanya. Banyak faktor yang menyebabkan kesenjangan digital itu terjadi, tidak hanya faktor demografis, jenis kelamin dan tingkat pendidikan. Literasi internet merupakan salah satu aspek dari kesenjangan digital (digital divide) yang sekarang terjadi di masyarakat. Dijk (2006 \& 2008, h.3) membagi kesenjangan digital menjadi menjadi empat, yaitu: akses material dan fisik, motivasi, keterampilan, serta penggunaan.

Faktor pertama dari kesenjangan digital adalah akses material dan fisik. Pengertian akses fisik sendiri adalah kondisi kepemilikan komputer/ gawai yang terkoneksi dengan internet, sedangkan akses material merupakan keseluruhan biaya yang dikeluarkan untuk pembelian perangkat keras, perangkat lunak, perawatan perangkat digital, serta layanan tertentu. Sehingga, masalah kesenjangan tidak dapat terselesaikan hanya dengan saat (hampir) semua orang memiliki komputer dan koneksi internet, namun dibutuhkan materi yang lebih daripada itu.

Karena secara otomatis apabila memiliki akses fisik perangkat digital, sudah harus bersiap dengan akses materialnya pula karena sudah menjadi satu kesatuan. Masalahnya, jika komputer dan produk elektronik (gawai) lainnya dari tahun ke tahun semakin murah, namun tidak dengan biaya yang dikeluarkan untuk media tersebut (akses material). Alasan tersebutlah membuat kesenjangan digital tersendiri karena dibutuhkan uang lebih untuk akses material perangkat digital itu sendiri.

Motivasi menjadi sumber selanjutnya dari kesenjangan digital. Motivasi sendiri merupakan dorongan dari dalam diri manusia masing-masing untuk melakukan tindakan tertentu. Kebanyakan orang berfikir kesenjangan akibat ketidakpunyaan akan barang digital seperti komputer, gawai dan sebagainya, namun lebih jauh ada juga orang tidak memiliki keinginan untuk menggunakan internet atau media baru dengan berbagai macam alasan.

Djik (2006 \& 2008: 4) juga menjabarkan alasan utama dari penolakan masyarakat akan penggunaan media baru diantaranya merasa tidak perlu/tidak butuh karena pekerjaan dan rutinitas mereka sehari-hari tidak menuntut untuk digunakannya 
media baru, tidak ada waktu untuk mengakses karena rutinitasnya seharian yang cukup padat, penolakan media baru karena masih asing untuk mereka sehingga dianggap sebagai media yang 'berbahaya', kekurangan uang untuk membeli serta merawat perangkat digital, dan kurangnya keterampilan untuk menggunakan perangkat digital membuat orang tersebut malas atau tidak ingin mempelajarinya.

Melengkapi penelitian dari Dijk (2008) tentang motivasi sebagai salah satu penyebab adanya kesenjangan digital, Halim \& Rahim (2011) menggolongkan motivasi menjadi 3 dimensi yaitu motivasi lingkungan, motivasi mental dan motivasi teknologi. Motivasi lingkungan berbicara tentang dukungan orang lain untuk menjelajahi Iaman e-agama. Motivasi mental merupakan wujud kenyamanan dan keyakinan seseorang terhadap informasi keagamaan. Serta yang terakhir motivasi teknologi adalah wujud perasaan butuh terhadap informasi keagamaan, dan menganggap internet merupakan teknologi canggih yang bisa memberikan informasi tersebut. Faktor motivasi dalam menggunakan media digital dalam penelitian yang lain juga dapat berfungsi sebagai sarana memanfaatkan internet sebagai ruang bertukar pikiran mengenai agama (McKenna \& West, 2007).

Kemudian terdapat faktor keterampilan/ skill/literasi. Memiliki motivasi serta kepemilikan akses fisik dan materi saja tidak cukup untuk menggunakan media baru secara maksimal jika tidak dibarengin dengan keterampilan. Dengan memiliki keahlian dasar tentang digital, dapat membantu seseorang untuk memecahkan masalah serta memiliki kemampuan berpikir yang lebih strategis (Servon \& nelson, 2001). Dijk (2008: 10) membagi konsep literasi digital ini menjadi 3 jenis meliputi keterampilan instrumental (instrumental digital skills), kemudian keterampilan informasi (informational digital skills) yang dipecah lagi menjadi 2 bagian yaitu keterampilan operasi formal dan substansial, terakhir adalah keterampilan stategis (strategic digital skills).

Keterampilan instrumental merupakan kemampuan paling dasar yang harus dimiliki, yaitu kemampuan seseorang dalam menggunakan perangkat keras (komputer, laptop, ponsel pintar, dII) serta perangkat lunak (aplikasi yang berada didalam perangkat keras). Sehingga sebelum lebih jauh berbicara tentang penggunaan internet, orang tersebut harus mampu terlebih dahulu mengoperasikan gawai dan internet secara dasar seperti mengaktifkan serta menonaktifkan gawai, berkirim pesan, mengunduh aplikasi, menggunakan aplikasi, menerima serta membuat panggilan, dan hal dasar lainnya terkait penggunaan gawai yang terkoneksi dengan internet.

Setelah memiliki keterampilan instrumental, terdapat keterampilan informasi. Keterampilan ini meliputi kegiatan mencari, memilih, serta memproses informasi pada komputer serta jaringan yang ada didalamnya. Tidak jauh berbeda, Halim \& Rahim (2011) melihat keterampilan informasi sebagai kemampuan seseorang untuk mencari, mengolah, serta memanfaatkan informasi.

Keterampilan informasi dibagi menjadi dua yaitu formal dan substansial. Keterampilan informasi formal meliputi pekerjaan yang berhubungan dengan karakteristik formal komputer dan internet seperti struktur file dan tautan. Sedangkan keterampilan informasi substansial meliputi kemampuan untuk menemukan, memilih, memproses, dan mengevaluasi informasi dalam komputer dan jaringan secara lebih spesifik. Keterampilan ketiga adalah keterampilan strategis yang memiliki kapasitas lebih dalam dengan penggunaan komputer yang terintegrasi dengan internet dengan tujuan tertentu dan untuk tujuan umum demi mempengaruhi derajat seseorang di dalam masyarakat (Dijk, 2006). Kemampuan ini membutuhkan keahlian serta pengetahuan komputer beserta jaringan atau aplikasi yang berada di dalamnya.

Faktor terakhir adalah faktor penggunaan, adalah bagaimana seorang pengguna media baru menggunakan perangkatnya. Faktor ini akan diukur dengan indikator waktu penggunaan; aplikasi penggunaan (jumlah dan keragaman); penggunaan broadband atau narrowband; serta keaktifan penggunaan kreatif. Sementara menurut Atmodjo (2014), faktor penggunaan diukur dengan durasi, frekuensi, situasi komunikasi, kondisi saat berkomunikasi, jenis aplikasi yang digunakan, jenis alat komunikasi yang digunakan. Lama tidaknya seseorang menggunakan media baru juga akan berdampak pada kesenjangan digital, karena biasanya orang yang lebih lama waktu penggunaannya lebih tahu seluk beluk media baru tersebut sehingga dapat menggunakannya secara maksimal. 


\section{METODE}

Penelitian ini menggunakan pendekatan kuantitatif dengan menyebarkan angket kepada 92 mahasiswa Fakultas IImu Komunikasi Universitas Pancasila. Survei dilakukan melalui bantuan google form yang diisi oleh responden yang telah dipilih oleh peneliti dari tanggal 5 sampai dengan 15 Januari 2019. Penelitian ini mengukur Variabel partisipasi politik secara daring dengan tiga dimensi berdasarkan tingkat literasi digital, yaitu: dimensi instrumental, informatif dan strategis.

Partisipasi politik instrumental bermaksud untuk mengkaji partisipasi politik responden dalam bentuk sederhana dan tidak membutuhkan kemampuan dalam menggunakan media digital, seperti: mendapatkan informasi; menonton/ membaca konten politik; dan memberikan respon berupa "like" pada konten politik. Dimensi ini diukur dengan 14 item peryataan. Partisipasi politik informatif dianalisis untuk melihat sejauhmana para responden mencari, mendapatkan dan mengolah suatu informasi politik. Dimensi ini diuji dengan 12 item pertanyaan dari dua indikator: mencari informasi dan berinteraksi dengan orang lain. Sementara partisipasi politik strategis diuji untuk melihat sejauhmana para responden terlibat dengan aktivitas politik dengan memproduksi konten, baik berupa opini maupun gambar, dengan tujuan untuk memengaruhi orang lain. Terakhir, dimensi partisipasi politik strategis diuji dengan 3 item, yaitu: membuat tulisan, membuat video dan membuat meme. Sementara itu, keseluruhan data dianalisis dengan menggunakan bantuan softwere SPSS 21.

\section{HASIL DAN PEMBAHASAN}

Penelitian ini telah mewawancarai 92 responden dari mahasiswa Fakultas IImu Komunikasi Universitas Pancasila dengan jenis kelamin laki-laki sebanyak $34.8 \%$ dan perempuan sebanyak $65.2 \%$. Kajian ini juga telah menguji partisipasi politik secara daring berdasarkan tingkat literasi digital dengan tiga dimensi, yaitu: instrumental, informatif, strategis. Data pada tabel 1 menunjukkan bahwa bentuk aktivitas untuk partisipasi politik instrumental yang paling banyak dilakukan melalui internet adalah memperoleh perkembangan informasi tentang Pilpres 2019 di media sosial (73.9\%). Bentuk partisipasi selanjutnya adalah "melihat Infografik mengenai Pilpres tahun 2019 di media baru" (68.5\%), melihat meme $(57,6 \%)$, dan membuka dan melihat tautan yang dikirimkan orang lain Mengenai Pilpres 2019 sebanyak $55.4 \%$ responden.

Tabel 1.

Tingkat Partisipasi Politik Instrumental

\begin{tabular}{|c|c|c|c|c|c|}
\hline No & Pernyataan & $\begin{array}{c}\text { Sangat } \\
\text { Tidak } \\
\text { Setuju } \\
\text { \% }\end{array}$ & $\begin{array}{c}\text { Tidak } \\
\text { Setuju } \\
\quad \%\end{array}$ & $\begin{array}{l}\text { Setuju } \\
\text { \% }\end{array}$ & $\begin{array}{c}\text { Sangat } \\
\text { Setuju } \\
\quad \%\end{array}$ \\
\hline 1 & $\begin{array}{l}\text { Memperoleh Perkembangan Informasi Pilpres } \\
2019 \text { di Media Sosial. }\end{array}$ & 0 & 5.4 & 73.9 & 20.7 \\
\hline 2 & $\begin{array}{l}\text { Orang Lain Mengirimkan Tautan Informasi } \\
\text { Pilpres } 2019 \text { Kepada Saya }\end{array}$ & 3.3 & 53.3 & 39.1 & 4.3 \\
\hline 3 & $\begin{array}{l}\text { Informasi yang berada di media sosial terkait } \\
\text { Pilpres } 2019 \text { sudah cukup akurat }\end{array}$ & 7.6 & 52.1 & 37 & 3.3 \\
\hline 4 & $\begin{array}{l}\text { Ketertarikan melihat blog tulisan orang lain } \\
\text { terkait Pilpres } 2019\end{array}$ & 3.3 & 41.3 & 45.7 & 9.8 \\
\hline 5 & $\begin{array}{l}\text { Membuka dan Melihat Tautan yang dikirimkan } \\
\text { Orang Lain Kepada Saya Mengenai Pilpres } \\
2019\end{array}$ & 2.2 & 35.9 & 55.4 & 6.5 \\
\hline 6 & Melihat Meme terkait Pilpres 2019 & 2.2 & 10.9 & 57.6 & 29.3 \\
\hline 7 & $\begin{array}{l}\text { Melihat Infografik mengenai Pilpres tahun } \\
2019 \text { di media baru }\end{array}$ & - & 17.4 & 68.5 & 14.1 \\
\hline 8 & $\begin{array}{l}\text { Menjadi Pengikut Akun Media Sosial Kandidat } \\
\text { Presiden tahun } 2019 .\end{array}$ & 9.8 & 51.1 & 26.1 & 13 \\
\hline
\end{tabular}




\begin{tabular}{|c|l|c|c|c|c|}
\hline 9 & $\begin{array}{l}\text { Menjadi Pengikut Akun Media Sosial Partai } \\
\text { Politik yang terlibat Pilpres 2019. }\end{array}$ & 15.2 & 66.3 & 12 & 6.5 \\
\hline 10 & $\begin{array}{l}\text { Menyukai (like) unggahan tentang Pilpres } \\
\text { 2019 di Media Sosial }\end{array}$ & 4.3 & 41.3 & 44.6 & 9.8 \\
\hline 11 & $\begin{array}{l}\text { Memberikan Komentar Singkat terhadap } \\
\text { Unggahan tentang Pilpres 2019 di Media } \\
\text { Sosial }\end{array}$ & 13 & 62 & 21.7 & 3.3 \\
\hline 12 & $\begin{array}{l}\text { Membagikan Tautan Konten Pilpres 2019 } \\
\text { kepada orang lain }\end{array}$ & 14.1 & 56.5 & 25 & 4.3 \\
\hline 13 & Mengunduh Konten Pilpres 2019 & 13 & 68.5 & 15.2 & 3.3 \\
\hline 14 & $\begin{array}{l}\text { Menandatangani Petisi Online yang } \\
\text { Dikirimkan Orang lain }\end{array}$ & 14.1 & 67.4 & 15.2 & 3.3 \\
\hline
\end{tabular}

Sumber: Olahan Peneliti

Sementara bentuk kegiatan yang sedikit

Pada tabel 2 menggambarkan hasil partisipasi dilakukan mengunduh konten Pilpres 2019 (15.2\%), menandatangani petisi online yang dikirimkan orang lain (15.2\%), dan menjadi pengukut akun media sosial partai politik (12\%). Hasil ini menunjukkan bahwa sebagian besar responden sudah melakukan untuk aktivitas politik secara daring yang sifatnya membaca atau melihat informasi/berita Pilpres, namun pada bentuk aktivitas yang bersifat terlibat lebih jauh baik itu menyimpan informasi politik maupun membagikannya ke orang lain masih sangat politik informatif. Hasil penelitian menunjukkan bahwa bentuk partisipasi yang banyak dilakukan oleh para responden adalah Mencari perkembangan informasi mengenai Pilpres 2019 melalui media sosial (66.3\%). Kemudian aktivitas "Mencari perkembangan informasi mengenai Pilpres 2019 melalui mesin pencarian" dilakukan oleh $64.1 \%$, dan "Mencari informasi lanjutan di media online lain berdasarkan informasi yang saya dapatkan di media sosial" dilakukan sebanyak $60.9 \%$. sedikit dilakukan.

Tabel 2.

Tingkat Partisipasi Politik Informatif

\begin{tabular}{|c|l|c|c|c|c|}
\hline No & \multicolumn{1}{|c|}{ Pernyataan } & $\begin{array}{c}\text { Sangat } \\
\text { Tidak } \\
\text { Setuju } \\
\%\end{array}$ & $\begin{array}{c}\text { Tidak } \\
\text { Setuju }\end{array}$ & Setuju & $\begin{array}{c}\text { Ssangat } \\
\text { Setuju }\end{array}$ \\
\hline 1 & $\begin{array}{l}\text { Mencari perkembangan informasi mengenai } \\
\text { Pilpres 2019 melalui mesin pencarian }\end{array}$ & 0 & 10.9 & 64.1 & 25 \\
\hline 2 & $\begin{array}{l}\text { Mencari perkembangan informasi mengenai } \\
\text { Pilpres 2019 melalui media sosial }\end{array}$ & 1.1 & 8.7 & 66.3 & 23.9 \\
\hline 3 & $\begin{array}{l}\text { Mencari informasi lanjutan di media online } \\
\text { lain berdasarkan informasi yang saya } \\
\text { dapatkan di media sosial. }\end{array}$ & 0 & 11.9 & 60.9 & 27.2 \\
\hline 4 & $\begin{array}{l}\text { Mencari data-data terkait kandidat pada } \\
\text { Pilpres 2019 di mesin pencarian }\end{array}$ & 2.2 & 21.7 & 57.6 & 18.5 \\
\hline 5 & $\begin{array}{l}\text { Mencari data-data terkait kandidat Presiden } \\
\text { tahun 2019 melalui akun media sosial } \\
\text { kandidat tersebut atau partai pengusungnya. }\end{array}$ & 3.3 & 34.8 & 52.2 & 9.8 \\
\hline
\end{tabular}




\begin{tabular}{|c|c|c|c|c|c|}
\hline 6 & $\begin{array}{l}\text { Pencarian informasi terkait partai-partai yang } \\
\text { terlibat dalam Pilpres } 2019 \text { di media baru }\end{array}$ & 3.3 & 33.7 & 56.5 & 6.5 \\
\hline 7 & $\begin{array}{l}\text { Membicarakan isu Pilpres tahun } 2019 \text { dengan } \\
\text { kenalan melalui media sosial }\end{array}$ & 9.8 & 49.8 & 34.8 & 6.5 \\
\hline 9 & $\begin{array}{l}\text { Berdiskusi dengan orang tidak dikenal di } \\
\text { media baru membahas isu Pilpres } 2019\end{array}$ & 19.6 & 52.2 & 22.8 & 5.4 \\
\hline 10 & $\begin{array}{l}\text { Berdebat dengan orang lain di kolom } \\
\text { komentar sosial terkait isu Pilpres } 2019\end{array}$ & 23.9 & 55.4 & 16.3 & 4.3 \\
\hline 11 & $\begin{array}{l}\text { Memberikan komentar di kolom komentar } \\
\text { media sosial dengan menyertakan data yang } \\
\text { relevan }\end{array}$ & 14.1 & 45.7 & 33.7 & 6.5 \\
\hline 12 & $\begin{array}{l}\text { Memengaruhi orang-orang untuk memilih } \\
\text { kandidat pilihan saya dengan menjelek- } \\
\text { jelekkan kandidat lainnya }\end{array}$ & 46.7 & 41.3 & 7.6 & 4.3 \\
\hline
\end{tabular}

Sumber: Olahan Peneliti

Sementara itu, aktivitas yang sedikit dilakukan oleh para responden adalah "Berdebat dengan orang lain di kolom komentar sosial terkait isu Pilpres 2019" (16.3\%) dan bentuk partisipasi "memengaruhi orang-orang untuk memilih kandidat pilihan saya dengan menjelek-jelekkan kandidat lainnya" sebanyak $7.6 \%$. Hasil pada tabel 2 dapat disimpulkan bahwa dalam partisipasi politik informatif keterlibatan responden untuk mencari infromasi politik sudah banyak dilakukan. Hanya saja, bentuk aktivitas yang sifatnya berdiskusi dan berdebat dengan orang lain di dunia maya masih dilakukan oleh bawah $34.8 \%-7.6 \%$ responden.

Selanjutnya pada tabel 3 adalah partisipasi politik strategis. Data menunjukkan aktivitas responden dalam dimensi ini masih sangat rendah, di mana aktivitas yang tertinggi hanya "Membuat tulisan untuk mengkritik atau mendukung isu-isu terkait Pilpres 2019 pada blog saya" oleh sebanyak $13 \%$, aktivitas "membuat video mengenai Pilpres 2019 dan mengulasnya ke media sosial" dilakuakn $6.5 \%$, dan membuat meme bertemakan Pilpres 2019 dan mengunggahnya ke media sosial juga dilakukan sebanyak $6.5 \%$ responden.

Hasil ini dapat disimpulkan bahwa bentuk partisipasi politik strategis masih sangat rendah dilakukan oleh para responden. Aktivitas yang banyak dilakukan hanya membuat tulisan dalam rangka mengkritik atau mendukung salah satu pasangan calon yang maju dalam kontestasi Pllpres 2019.

Tabel 3.

Tingkat Partisipasi Politik Strategis

\begin{tabular}{|c|l|c|c|c|c|}
\hline No & \multicolumn{1}{|c|}{ Pernyataan } & $\begin{array}{c}\text { Sangat } \\
\text { Tidak } \\
\text { Setuju } \\
\%\end{array}$ & $\begin{array}{c}\text { Tidak } \\
\text { Setuju }\end{array}$ & $\begin{array}{c}\text { Setuju } \\
\%\end{array}$ & $\begin{array}{c}\text { Sangat } \\
\text { Setuju }\end{array}$ \\
\hline 1 & $\begin{array}{l}\text { Membuat tulisan untuk mengkritik atau } \\
\text { mendukung isu-isu terkait Pilpres 2019 pada } \\
\text { blog saya }\end{array}$ & 31.5 & 51.1 & 13 & 4.3 \\
\hline 2 & $\begin{array}{l}\text { Membuat video mengenai Pilpres 2019 dan } \\
\text { mengunggahnya ke media sosial }\end{array}$ & 35.9 & 53.3 & 6.5 & 4.3 \\
\hline 3 & $\begin{array}{l}\text { Membuat meme bertemakan Pilpres 2019 } \\
\text { dan menggunggahnya ke media sosial }\end{array}$ & 29.3 & 63 & 6.5 & 1.1 \\
\hline
\end{tabular}

Sumber: Olahan Peneliti 


\section{SIMPULAN}

Berdasarkan temuan dan analisis data, penelitian ini memberikan simpulan bahwa para generasi Z lebih banyak melakukan partisipasi politik instrumental dan informatif dibandingkan strategis. Meskipun demikian, sebagian besar responden lebih banyak melakukan aktivitas yang sifatnya melihat atau membaca saja, sementara aktivitas menyimpan informasi dan melibatkan orang lain seperti membagikan tautan dan menjadi bagian dari komunitas gerakan politik di media sosial hanya sedikit yang terlibat.

Hasil penelitian ini berbeda dengan Umar \& Kurnia (2019) yang menemukan Informatif lebih tinggi dibandingkan dengan partisipasi instrumental dan strategis. Salah satu faktor terjadinya perbedaan karena dalam penelitian ini hanya menguji generasi $Z$, sementara Halim dan Dyah menguji semua usia, di mana tingkat ketertarikan politik di usia lebih dari 35 tahun lebih tinggi dibandingkan generasi $Z$.

Partisipasi politik informatif dalam temuan penelitian ini juga sudah banyak dilakukan oleh para responden, khususnya item-item yang diuji dari indikator mencari informasi. Hal ini dibuktikan dari indikator "mencari informasi" telah dilakukan oleh lebih dari 50\% responden. Hanya saja indikator "berinteraksi dengan orang lain" masih sedikit dilakukan. Jika dilihat dari data tabel 2 item pernyataan yang diuji dari indikator berinterkasi di bawah $50 \%$.

Sedikitnya partisipasi politik strategis bisa dikarenakan faktor kemampuan menggunakan teknologi, pengetahuan politik yang minim dan ketertarikan pada isu politik. Sementara tinggi dan rendahnya partisipasi politik online secara keseluruhan dapat disebabkan oleh faktor tidak adanya motivasi untuk melakukan aktivitas politik. Beberapa faktor di atas menjadi saran penelitian ini untuk penelitian-penelitian selanjutnya. Sehingga generasi muda ke depan bisa memanfaatkan internet untuk mengetahui perkembangan politik lokal maupun nasional, karena dengan mengetahui kondisi politik secara tidak langsung kita mendorong generasi muda untuk memahami kondisi dan nasib bangsa dan negara.

\section{DAFTAR PUSTAKA}

Akmal, F., \& Salman, A. (2015). Partisipasi Politik Belia Secara 'Online' Melalui Ruang Demokrasi Maklumat Media Baru. Malaysian Journal of Communications, 3(1), 81-100.

Arifin, A. (2013). Politik Pendidikan Tinggi Indonesia. Jakarta: Penerbit Pustaka Indonesia

Atmodjo, T. J. (2014). Dinamika Portisipasi Politik Remaja Melalui Media Sosial. Jurnal Visi Komunikasi, 13(2), 281-295.

Budiardjo, M. (2013). Dasar-Dasar Ilmu Politik. Jakarta: PT Gramedia Pustaka Utama.

Dewi, S. F. (2017). Sosiologi Politik. Yogyakarta: Gre Publishing.

Dijk, J. A. G. M. V. (2006). Digital Divide Research, Achievements and Shortcomings. Poetics, 34, 221-235. DOI: 10.1016/j/poetic.2006.05.004.

Dijk, J. V. (2008). Routledge Handbook of Internet Politics. Canada: Routledge.

Halim, U., \& Rahim, S. A. (2011). Penglibatan Digital: Akses dan Penggunaan E-Agama dalam Kalangan Generasi Muda Muslim. Malaysian Journal of Communications, 27(2), 121-135.

Halim, U., \& Dyah, K. (2019). Pengaruh Terpaan Media Terhadap Partisipasi Politik dalam Pilkada DKI Jakarta 2017. Jurnal ASPIKOM, Vol.4 (1), 45-59.

Harun, R., \& Sumarno. (2006). Komunikasi Politik sebagai Suatu Pengantar. Bandung: Bandar Maju.

McKenna, K. Y. A., \& West, K. J. (2005). Give Me That Online-Time Religion: The Role of The Internet in Spiritual Life. Computers in Human Behavior 23(2007) 942-954. DOI: 10.1016/j. chb.2005.08.007.

Mudjiyanto, B. (2012). Literasi Internet dan Partisipasi Politik Masyarakat Pemilih dalam Aktivitas Pemanfaatan Media Baru. Jurnal Studi Komunikasi dan Media, 16(1), 1-17.

Perangin-angin, L. L. K., \& Zainal, M. (2018). Partisipasi Politik Pemilih Pemuka dalam Bingkai Jejaring Sosial di Media Sosial. Jurnal ASPIKOM, 3(4), 737-754.

Rasul, N. M., Rahim, S. A. R., \& Salman, A. (2015). Penggunaan Media, Norma Kewarganegaraan, dan Partisipasi Politik dalam Era Transisi ke Demokrasi di Indonesia. Malaysian Journal of Communications, 31(1), 187-204. 
Rohaniah, Y \& Efrizah. (2015). Pengantar Ilmu Politik. Malang: Intrans Publishing.

Salman, A., \& Saad, S. (2015). Online Political Participation: A Study of Youth Usage of New Media. Mediterranean Journal of Social Sciences, 6(4). DOI: 10.5901/mjss.2015. v6n4s3p88.

Salman, A., Salleh,N. A. M., Yusoff, M. A., \& Abdullah, M. Y. (2018). Political Engagement on Social Media as Antecedent for Political Support among Voters in Malaysia. Malaysian Journal of Communications, 34(2), 152:165. DOI: 10.17576/JKMJC-2018-3402-10.

Syafiyyah, A. (2003). Kiprah Politik Muslimah. Jakarta: Gema Insani. 